\title{
Residents Perception on Child Abuse and Influence on Social Studies Students' Academic Achievements
}

\author{
Edinyang, Sunday David \\ Ekuri, Patrick George \\ Ushie, Doris Emmanuel \\ Department of Social Science Education \\ Faculty of Education \\ University of Calabar \\ Pmb 1115, Calabar, Cross River State \\ Nigeria.
}

\begin{abstract}
Social studies is a discipline that deals with social change and ensures that meaningfully interaction of the recipients with their physical and social environments is attained. It engenders sound education of the citizens, as well as inculcates a sense of social consciousness and social responsibility. Social studies a study that can help an individual to understand his environment, find out the problems of his environment as well as solving existing social problems. It is a study that inculcates the value of honesty, cooperation, and the needs of the nation, as well as the desirable skills to solve environmental problem. It is against this background that mass failure of students on the subject has resulted to several reactions by members of the public. Could child abuse be the remote cause to low academic achievement of students in social studies?
\end{abstract}

Keywords: Perception, Influence, Child Abuse, Social Studies, Achievement.

\subsection{Introduction}

In Nigeria, the structure of the child's rights Act 2003 (CRA) defines a child as one who is below the age of eighteen years. It categorically provides that such a child's best interests shall remain paramount in all considerations. A child shall be given such protection and care as is necessary for its well beings, retaining the right to survival and development in all ramifications, unfortunately and contrarily to the child right Act, children today across the globe are subject to all forms of inhuman act or maltreatment (abuse). Child abuse an ancient evil with modern face is an agelong practice in the history of mankind. It has existed in various forms in various parts of the world since ancient time (Davey, 2010).

In the past, the public, as well as related bodies, often perceived instances of child abuse to be avoided cases rather than part of a widespread phenomenon. As a result, child maltreatment did not gain widespread attention until late $21^{\text {st }}$ century when a few high profile abuse incidents of children are made public. These acted as the catalyst in prompting the governments across board to introduced the child protection act in 1991. According to the Child Act 2001, child abuse is define as when the child has been or is at substantial risk of being physically or emotionally injured or sexually abused or neglected in terms of adequate care, food, shelter, clothing, medical attention, supervision and safety, or abandonment or others such as being on the street or used for begging by the parents or foster parents (guidance) as the case may be. This ugly trend has attributed several resident perception about the phenomena. Child abuse have recently been recognized by the World Health Organisation as having broad implications for human development and the prevention of public health problems and negative effects on academic achievement of students, especially social studies students. It is on this background that the study seek to investigate the residents perception of child abuse and influence on academic achievement of social studies students in Calabar South Local Government Area of Cross River State.

Child abuse according to Odey (2017) refers to all intentional act that result in physical, psychological, emotional, or sexual harm to children. It covers a wide range of behaviour from actual physical assault by parents or other adult, caregiver to neglect of a child's basic needs. According to Coonan (2004) child slavery is a far-reaching and complex problem in developing countries. The types of child abuse vary according to the country's culture and the family culture, rural or urban residency, socio-economic condition and existing level of development, among other factors. 
Child abuse takes various forms such as; child labour, physical abuse, sexual abuse, psychological abuse and street hawking. International labour organisation (ILO) (2010) reports that largest numbers of various forms of abused children are found between children of the age of 5-14 live in Asia and Africa. According to its survey $41 \%$ of all children particularly of school age between 5 and 14 years old are involved in economic activity in Africa as against $21 \%$ of all children in Asia, and 17\% in Latin America. In Calabar metropolis, it is noticed that daily there is a rise in the number of children who litter the street in search of living, with its attendant consequences on the academic achievement of students. According to Ezeadi (2010) one's education is closely linked to his life chances, income and wellbeing. Therefore, it is important to have a clear understanding of what benefits or hindered once educational attainment. However, in spite of the important role of education, the researcher observe that academic performance of students are been affected by their vulnerable situations, that often deprived them of effective participation in school activities. Most students in Cross River State are daily confronted with challenges of coping with academics under serious emotional strains, occasioned by long walk to school, unfriendly school environment and unmotivated home and child labour (UNICEF, 2008).

This study, according to the researcher would be discussed on the most prevalent forms of child abuse, child labour, physical and emotional abuse.

\subsection{Statement of the Problem}

The problem of low academic achievement of students in social studies has long been a source of concern to education stakeholder. Several researches have been carried out without a definite solution or answer to the problem. This arouses the curiosity of the researcher, to find out the factor responsible for poor performance of students. What could be responsible for this failure, can students performance be attributed to child abuse or neglect.

There are number of literature on the effect of child abuse on the moral and social development of children elsewhere in Nigeria and many other parts of the world. However, non of these studies seems to address in details the relationship between child abuse and academic performance of the children in Nigeria, and in Cross River State in particular. It is a on account of this that, the study is carried out to investigate residents perception of child abuse influence on social studies students academic achievement.

\subsection{Purpose of the Study}

This study sought to investigate resident perception of social studies student academic achievement in Calabar South Local Government, Area of Cross River State.

\subsection{Research Question}

- What is the resident perception of child abuse and influence on social studies students' academic achievement.

\subsection{Statement of Hypothesis}

There is no significant influence of child abuse on social studies students academic achievement.

\subsection{Residents Perception of Child Abuse and Academic Achievement of Students in Social Studies.}

\subsection{Child labour and academic achievement of students}

Scanlon (2002) refers to child labour according to articles 32 of the conventions on the rights of the child, includes any economic activities impeding or hindering the child's full development on education. UNICEF 2010, described childlabour as work that violates childrens human rights. The international labour organisation categorized child labour as follows: Agricultural labourers - Domestic Labourers - Streets Labours and - factory labourers with wages

Child labour remains a major source of concern in Nigeria, inspite of legislative measure taken by the government at various levels. Report by International Labour Organisation (ILO) estimated that $24.6 \%$ of children between the age 10-14 in Nigeria were working. It is a ridiculous sight in most big cities, as well as rural villages today to see children of school age, trading food on the street, herding animals, tanning and dying raw leather product, fetching water for commercial purpose, washing dishes at restaurants, serving as domestic servants, selling wares at kiosks, collecting fire wood for business, harvesting crops in family farm or commercial plantation amongst other activities (Odey, Ita and Nchor, 2017). Obinaju (2005) look at child work in the perspective of culture. To the author, child labour covers tasks and activities that are undertaken by children to assist their parent or guardians. In this case child labour simply aims at tasks and activities which are geared towards the socialization process, if education must be wholesome.

However, the International Labour Organisation (2010) strongly condemned child labour, under this abuse children prematurely leading adult lives, normally working long hours for low wages under conditions damaging to their health, physical and mental development, sometimes separated from their families, frequently deprived of meaningful educational training opportunities that could open for then a better future. 
Child labour is generally interpreted as "all cases in which children are exposed to harm at work whether or not children are less than 14 years old or less" (UNICEF, 2005).

Honsin (2007), states that most times children labourers go through physical and health consequences such as respiratory problems, injuries, accidents physical and sexual abuse such as rape and molestation, malnourishment, extortion of income, police harassment, and participation in harmful delinquent activities all inimical to educational successes. Recently the International Labour Organisation (ILO 2013) estimated they are around 215 million children between the ages five to fourteen works worldwide. They are often mistreated and work for prolong hours, in very bad conditions. This can affect their health physically, mentally and emotionally. These children do not have the basic rights like access to school. Sabate and Rayah (2011) assert that child labour impacts negatively on the achievement or performance of basic education because it leads to high drop rates as it easy for children to be easily deceived by meagre income that trickle in, believing that leaving school to give more time and attention to their work is better option as they will get rich faster than their peers who have to spend many years in school. This can also lead to low academic achievement/poor performance on account of which the child would be expected to repeat a grade, that can cause fear, low self-esteem shame both on the parts of the child and parents and make them to develop certain apathy for schooling and in such cases, and drop out could be a possible consequence. In some situations, such children are considered poor and unfit for academic pursuits and the tendency is usually to pull them out of school for a certain trade or apprenticeship thereby perpetrating further abuses since many poor parents may not be willing to give them second chance. There is trade off by most parents between the time children spend in labour and that spent attending school and doing some school related assignment. Majority of child labourers either do not attend school or skip school to various degree (Ekwe 2002). The general notions held by many is that child labour is detrimental to learners academic capability.

Okafar (2010) and other school of thoughts believes and sees child labour as an inevitable process of growth, development and integration of the child as stated in the social theory. There is a belief that street hawking prepared the children for adult roles. It is believed according to the functionalist conceptualization, this forms of socialization groomed individuals to become industrious. In most part of Nigeria, most children are integrated into the family occupation early in order to acquire a better standing in such vocation or trade. Despites, the various argument, it was found out that child maltreatment is widely considered as responsible for a negative effect on children's academic achievement. Abused students tend to have less concentration span in class. Alokan and Olatunji (2014) carried out a study on the influence of child abuse on classroom behaviour and academic performance among primary and secondary school learners in Ekiti State, Nigeria. All teachers in both primary and secondary schools in public and private sectors in Ado Local Government Area of Ekiti State were target for the study. The study found out that there is a significant relationship between children's active involvement in parents business and their attitude to class work.

The number of child labour is increasing in Nigeria, in 1995, the number of child labour was twelve million while by 2006 the number of child labour under the age fourteen has risen to fifteen million (Adegun, 2013). The international labour organisation estimates that about 25 percent of Nigeria's 80 million children works in different sectors such as farms, domestic help, in fishing, mining, armed, conflict, street hawking, and child trafficking. The number of child labour involved in street hawking is very common form of child labour in Nigerian cities, these children working from morning to evening and as a result of this, they do not have the time to enrol in schools or most of them drop out of school (Adegun, 2013). Awosusi and Adebo (2012) assumes that many child labour in Nigeria are abused physically, mentally, sexually and psychologically.

Umobong (2010) in a study on child labour used a sample of four hundred and twenty respondents. Date were collected through a well validated instrument. Simple percentage and chi-square $\left(X^{2}\right)$ statistical techniques were used for the analysis. From the findings it described child labour as any physical action that inflicted on the wellbeing of the child. Obinaju (2005) in a study on child labour and its effects on the child selected a sample of two hundred students (200) through the stratified random sampling technique. A six points likert-type scale was the instrument used for data collection. Data collected were analysed through independent t-test analysis he describes child labour as an exploitative systematic process in which children are used for jobs that are monotonous, strenuous, harmful or unduely prolonged. In many instances, this category of children are made to grow up prematurely and sadly, instead of leading them to carefree existences with their friends and peers during what should be the happiest days of their lives.

Also Moses (2005) conducted a study on child labour and its effects on the child. He used two hundred and fifty (250) respondents as his sample. Simple random sampling technique was adopted for the selection of the sample. Data were collected through the questionnaire. Pearson product moment correlation analysis was used for data analysis. 
It was lamented that child labour still remains a serious problem in many parts of the world against the United Nations Conventions on the Rights of the Child (UNCRC), which state clearly that governments should recognize the rights of the child to be protected from economic exploitations and from performing any work that is likely to be hazardous, or harmful to the child's development or those that interfere with child's education (UNCRC in Parekh 2001).

Denga \& Denga (2007) interviewed 11 street hawkers within Uyo town and their ages ranged from 7-18 years. Six (6) males and five (5) females were involved in selling assorted agricultural products like tomatoes onions, yams, vegetables, second hand clothing. This list inexhaustible, some of these children dropped out of school due to poverty and financial crises in the family. Street hawking is a form of child abuse which may enhance the child development negatively irrespective of the economic gain. It stands out as one of the suspects that affect poor academic performance among school students. The implication of hawking is that it affects learning opportunities.

\subsection{Physical abuse and social studies students' academic achievement}

Physical abuse involves physical aggression directed at a child by an adult. Most nations with child abuse laws consider the deliberate infliction of serious injuries, or actions that place the child at obvious risk of serious injury or death, to be illegal. Bruises, scratches, burns, broken bones, lacerations, as well as repeated "mishaps" and rough treatment that could cause physical injury, can be physical abuse.

The problem of child bettering (human torture) remains controversial some see the problem as a response to stressful circumstances and society permissive attitude to violence, while others view its as primarily a manifestation of parental maladjustments. To Springer (2007) physical abuse refers to harmful actions directed against a child. It involves any inflicted injuries such as bruises, burns, fractures, poisoning, sticking, kicking or any other actions that result into a physical impairment of the child. Alokan (2014) conceived that physical abuse could lead to severe injuries, bruises, burns, incapacitation, disability or even death.

The state of insecurity, influence by child abduction and kidnapping, constituted another forms of child physical abuse, where most of the student victims pass through a "nightmare" which serve as a bane to academic achievement of student. Biologically, young children are known to have lower heart tolerance than adult, as such brain heat, and organ danger could lead to slow learning. Uzoezie(2005) reported a case of a woman who beat her son to a state of coma just because he played football. The author further gave an experience of a secondary school teacher who subjected his students, noted for truancy to carry block on his kneel for an hour. In another case, a boy was deprived from eaten for 48hours for stealing neighbour's money. Okafor (2010) gave report of a school teacher at Onitsha who kneel her child down for a long time in a rough floor in the office because he was a perpetual fighter in school. These got the child's knees swollen. Most teacher respond to every mistake of their learners with severe punishment, especially with the students seem to be a slow learner (Horsch 2010).

Uzoezie (2005) opined that child physical abuse can lead a child to sustain open wound, scars, bruises, fractures or can even stop growth. Isangedighi (2005) points out that child bettering is a global phenomenon. In the United State of America (USA) for instance, about 14\% of the children are abused, 2,000 die as a result of the abuse. An average of 1,000 to 5,000 children dies each year in USA as a result of injuries arising from maltreatment. Adegun (2013) conducted a study on the incidence of rape among children in Oyo State, using random sampling of 270 respondents. The result revealed that, between $27 / 5 \%$ and $43.4 \%$ of all reported cases of rape were children under the age of 17years.

United Nation International Children Emergency Fund (UNICEF) (2003), in a global study on violence against children, reveal that almost 53,000 children died worldwide in 2002 as a result of homicide. Up to $80 \%$ of $98 \%$ of children suffer physical punishment resulting from the use of implement. The study also revealed that 150 million girls and 73 million boys under 18yrars experienced maltreatment and most of them were affected with negative behaviour, with poor education as after consequences. The general review on child physical abuse shows that battering of all kinds analyzed by different reports are detrimental to academic performance of students at various levels.

Obinaju (2005) conducted a study on child physical abuse and their performance in school. He used a sampled of three hundred (300) students selected randomly through the simple random method. Four point likert scale questionnaire was used for data collection. Data were analyzed using one-way analysis of variance (ANOVA). The finding reveals that female genital mutilation as one of the form of physical abuse causes harm to the physical body of the girl child. Child physical abuse according to Obinaju may result to improper education of the child, loss of opportunities in life, poor performance in school, dropping out of school, and even developing low self-esteem. These indices are negative indicators of good academic performance of students. 
Child physical abuse is seen by many authors as a form of child abuse which can cause harm to the child. For a child to perform well academically, he needs a stable mind. The implication of it is that students who developed low selfconcept tends to develop poor learning attitudes hence, perform poorly in their studies.

\subsection{Child Neglect and Social Studies Students' Academic Achievement:}

Child neglect, psychological and emotional abuse are related forms or aspects of child abuse that would be use interchangeably. Child neglect is the failure of parent or other person with responsibility for the child to provide needed food, clothing, shelter, medical care, or supervision to the degree that the child's health, safety, and well being are threaten with arm. Neglect is also lack of attention from the people surrounding a child, and the non-provision of the relevant and adequate necessities for the child's survival, which would be a lacking in attention, love, and nurture. Some of the observable sign in a neglected child include; the child is frequently absent from school, begs or steals food or money, lack needed medical and dental care, is consistently dirty, or lack sufficient clothing for the harsh weather.

Emotional abuse is defined as the production of psychological and social defects in the growth of a child as a result of behaviour such as loud yelling, coarse and rude attitude, inattention, harsh criticism, and denigration of the child's personality. Other examples include name-calling, ridicule, degradation, destruction of personal belonging, torture or killing of a pet, excessive criticism and routine labelling or humiliation. Neglected children may experience delays in physical and psychological development, possibly resulting in psychopathology and impaired neuropsychological functions including executive function, attention, processing speed, language, memory and social skills. Emotional abuse/maltreatment is a problem that is affecting people of all races, religions, socio-economic groups, sex, and ages (Hosin 2007).

The American Human Association (AHA, 2010) defines emotional abuse as pattern of behaviour by parents or caregivers that can seriously interfere with a child's cognitive, emotional, psychological or social development. This clearly points to the fact that parents and teachers have the tendency to inflict emotional abuse on their children. The emotional maltreatment meted out to adolescent at home and school comes in different forms and diverse circumstances. It manifest in unkempt appearance, inappropriate dressing, anger, unbalance diet, subjection to all forms of labour abuses and sexual violence. Emotional or psychological abuse is all encompassing, because, it is the resultants consequencies of all the respective hazard suffered from all the other forms of child abuse (child labour, sexual abuse, physical abuse etc), therefore, discussion on child emotional abuse is all embracing because of it connectivity with child neglect and other abuse (Hosin 2007).

Accurate statistics on the prevalence of adolescent who suffered emotional maltreatment are rather difficult to come across because there are under reported or difficult to detect. Eriba (2004) reports that emotional abuse tops the list of other abuses, data on the prevalence of emotional abuse notwithstanding.

Okpara (2001) conducted a study on child neglect and academic performance of study. A sample of 400 students were used. Analysis of variance (ANOVA) was used to test the generated data. From the finding he confirmed that child neglect includes inadequate feeding, shelter and lack of supervision, inadequate general body care, inadequate dental care and general poor attention. Onyeanu (2005) in a report on child neglect and academic performance used a sample of one hundred and fifty (150) randomly selected through the simple random technique. Data collection were analyzed using pearson product moment correlation analysis, from the finding, it was deduced that lack of provision of materials for class work for the child is a form of child neglect. Many parents deny their children the right to material for class work and therefore causing them to perform poorly academically. The implications of child neglect, emotional and psychological abuse on students academic performance is that, when the student are denied the basic material that enhances learning like school uniform, textbooks and paying of school fees as at when due, it affect the performance of such student.

Child abuse is the physical, sexual or emotional maltreatment or neglect of a child or children. Child abuse can occure in a child's home, or in the organisations, schools or communities the child interacts with. There are four major categories of child abuse: neglect, physical, psychological or emotional abuse, and sexual abuse. According to the (American) National Committee to prevent Child Abuse, in recent time, neglect represented 54\% of confirmed cases of child abuse, physical abuse $22 \%$, sexual abuse $8 \%$ emotional abuse $4 \%$ and other forms of maltreatment $12 \%$.

From the literature reviewed about residents perception of child abuse on academic performance of student, one can clearly said that there are negative feelings and news about child about child abuse, because, it discover that many children bore into the society have been abused in one way or ther other and at one level or the other. Child abuse of various kinds according to the authors are seen as one of the factors that caused low academic achievement, low selfesteem and school dropout among children. Constant practice and involvement of these acts by abusers leads to negative educational result. 


\subsection{Child Abuse Causes, Effects and Remedies}

Child abuse is a complex phenomenon with multiple causes understanding the causes of abuse is crucial to addressing the problem of child abuse. Parents who physically abuse their spouses are more likely than others to physically abuse their children. There are several factors associated with child abuse such as cultural influence, poverty/economic status of parents), low education, unemployment, inability to cope with the needs of the family members, street life and single parents families, lack of sponsorship by poor school performance, large family size, peer group influence, parental pressure etc. Studies have demonstrated that the most notable reason being poverty (Bhat \& Rather, 2009). Decision about child labour for instance and schooling are generally made by parents. If the family live below the poverty line, parents see children as part of contributor in their family income. Basu (2008) used a theoretical model of child labour, where he showed the only reason parents send children to labour is because of their income. Consequently poor parents cannot afford schooling for their children. Thus, mainly poor households are to send their children to all forms of labour instead of sending to school. Rena (2009) shows that poverty and underdevelopment drives child abuse of all kinds. Unemployment and financial difficulties are associated with increased rate of child abuse. It is believe that child abuse in Nigeria increase during the economic recession.

According to the researcher field survey compared with other studies, examined the causes of child abuse in Nigeria, and Cross River State in particular. In these respective findings, 34\%, 43\%, 19\%, and 44\% of children reported at least one type of child abuse. According to these survey, there are series of correlations between the potential risk factors of parental employment status, alcohol abuse, and family size within the abuse ratings.

Effects of Child Abuse on Academic Performance

Child abuse can result in immediate adverse physical effects but it is also strongly associated with developmental issues and with many chronic physical and psychological effects, including subsequent-ill-health, including higher rates of chronic conditions, high-risk health behaviour, shorten lifespan and influence on the academic performance of students.

Davey (2010). Child participation in class is positively related to academic achievement. Children in the school can fail to participate in class activities due to abuse, lack of interest, inattentiveness of different kind of learning problems. Spinger (2007) assert that child maltreatment can influence children's performance of competencies. Alokan and Olatunji (2014) found out that child maltreatment is widely considered as responsible for a negative effect on children's academic achievement. Abused students tend to have less concentration span in class. These authors carried out a study on the influence of child abuse on classroom behaviour and academic performance among primary and secondary school learners in the Ekiti State of Nigeria. The study found out that there is a significant relationship between children's active involvement in parents' business and their attitude to class work. Based on the findings, it was recommended; among others thing the effects of child abuse on children's classroom behaviour and later academic performance should received attention in education policy. Parents should always relate to their children with love and affection and also provide for their needs.

Furthermore, Umobong (2010) asserted that child abuse it now prevalent in schools with negative consequences on the educational development of children. Theoklitou, Kabitsis and Kabitsis (2012). Submitted that abused children's intelligence is low as a result of neglect and psychological trauma. These authors also (2001) revealed that the three types of learning are behaviourist, cognitive and social learning theories. These theories explain how children are taught and how learning is expected to take place. Abused children therefore do not learn effectively hence they perform poorly in school. Children that have been victimized by one or more forms of abuses exhibit some behaviours different from others in school with attendant effects on their academic performance. Child abuse generally delays student's progress academically, because, there is always lack of trust on people because they have been disappointed and abuse by those that ought to be trusted. United State Department of Education (USDE) (2005) revealed that abused children perform less than their mate academically in school.

According to Bassey (2012), a study on child labour and its consequences on the Nigeria education using 500 respondents revealed that $52 \%$ of children are abused in Calabar. The study asserts that child abuse and poverty, unemployment and school dropout are related.

\subsection{Summary of literature review}

In this study literature review concerning child abuse and academic performance of students' have been attempted. According to various perception authorities have said about child labour, child physical abuse and child neglect affects students. From the literature so reviewed, one can see that many children born into the society have been abused in one way or the other and at one level or the other. Children are supposed to be cared for by their parents. If their needs are not adequately met, they may not do well in school and society. Child abuse has been seen by most authors as one of the factors that may be responsible for low academic achievement of children. 
Despite the growing national and international concern on child abuse, the phenomenon is been perpetrated at a high level. Child abuse takes several forms, the four main types are child labour (street hawking), physical (child bettering) abuse, child neglect and child sexual abuse. According to reviewed literatures, the cases were substantiated as: child neglect $68.3 \%$, physical abuse $18.6 \%$ and child labour $17.3 \%$. According to the review, child neglect or abuse is rated the commonest, because its form part of every actions carry out at all scene, but very silent and unpopular because of it unidentical prove. It is an abuse that is unconsciously carried out among all human race and in all relationship.

Several researches have been carried out on this primary variable (child abuse), but non was specifically focus on Calabar South Local Government Area, of Cross River State. The other gap also fill by this study include use of secondary school students compare to previous works that were restricted to primary school. The study would add to the existing knowledge in the field of academic.

\subsection{Methodology and procedure for data collection}

Ex post facto research design was adopted. The researcher vehemently considered this survey design suitable for the study since causes are studied after they presumably exerted their effects on other variables before the researcher gets there. A self-developed questionnaire validated by two test experts from science education department of University of Calabar, Calabar with a reliability of .92 and 76 established through cronbach alpha was used for data collection. A-15 item questionnaire and a 40 item achievement test were the instrument used to gather data for the study. Simple sampling technique method was applied. One hundred (100) upper basic (JSS 3) students were randomly selected from five school out of the seven (7) public secondary schools in Calabar South Local Government Area within the targeted area of study. The data gathered were coded according to the variables. Analysis of data was carried out based on the one research question and hypothesis respectively. The variable was identified with an appropriate statistical technique for testing. The responses from the question and the achievement test were analyzed using crombach alpha estimate for the questionnaire and Kuder- Richardson (KR 20) for the achievement test.

Result of reliability estimate of child abuse questionnaire and students academic achievement

\begin{tabular}{|c|c|c|c|c|c|c|}
\hline $\mathbf{S} / \mathbf{N}$ & Variable & No of item & No of rep & $\mathbf{X}$ & SD & $\begin{array}{l}\text { Cronbach } \\
\text { coefficient }\end{array}$ \\
\hline 1. & Child labour & 50 & 100 & 14.47 & 2.90 & .90 \\
\hline 2. & Child physical abuse & 50 & 100 & 15.33 & 2.0 & .92 \\
\hline 3. & Child neglect & 50 & 100 & 8.80 & 2.59 & .79 \\
\hline 4. & $\begin{array}{l}\text { Social } \\
\text { achievement test. }\end{array}$ & 40 & 100 & 24.37 & 1.76 & 0.64 \\
\hline
\end{tabular}

The child physical abuse has $92 \%$ with the highest influence followed by child labour with $90 \%$ and the least of them is the 76\%. This indicated the level of the impact of child abuse in on academic performance of students. In order words, child physical abuse is the most critical problem that influences academic achievement of the JSS 3 students in social studies in Calabar South Local Government Area of Cross River.

\subsection{Discussion of findings}

The correlational statistical analysis with child abuse and students academic performance shows that there is indeed an inverse relationship between child abuse and students academic performance. This implies that the nature of treatment that a child is subjected to is significantly related or influence the child performance in school. This finding is inline with UNICEF (2008) that observed that the phenomenon of child labour is arguably the tatest challenges that impacts directly on school enrolment, attendance, academic performance, completion rate as well as health rest, leisure and the general psychological deposition of children.

The result of this study also showed that child physical abuse affect the academic performance of learners. The present finding is in agreement with Odey (2017) who asserts that physical abuse could lead to severe injuries, bruises, burns, incapacitation, disability or even death. According to the author and this finding, child battering may result to improper education of the child, lost of opportunities in life, poor performance in school and even developing low self-esteem.

The finding of this study revealed that neglect is significantly related to student academic performance in secondary school. This implies that the behaviour of parents or caregivers interferes with the child academic performance in school. This finding is in tandem with Alokan and Olatunji (2014) who confirmed the relationship between parents, emotional abuse on self-concept and worth of the child. The authors stated that emotional abuse or child neglect or threat could lead to negative attitude to schooling. The abused respondents who participated in this study indicated that as a result of different forms of abuses, they get low scores in assessment, class activities and examinations. 
This agreed with Okarfor (2010) that abused children are more likely to repeat a grade, do poorly on cognitive tests and have discipline problems in school. The study in summary shows that child abuse affects the academic performance of secondary school learners in Calabar South Local Government Area of Cross River State.

\subsection{Conclusion}

The study states clearly that child abuse is very popular, suffered by most secondary school students in Calabar South Local Government Area of Cross River State. It will not be an over statement to say that child abuse especially variables discussed above are some of the $21^{\text {st }}$ century greatest challenges to socio-economic development. As already noted, the phenomenon has traumatized many and is denying a vast number of children in the developing world access to schooling, thus making education for all (EFA) by the 2025 more of a mirage than a reality. The result of this study specifically reveals that poor performance are unavoidable characteristic of child abuse, as children who are victims of one abuse or the other have limited period of academic concentration. In others to promote students good academic performance, all forms of child abuse should be avoided. Child abuse variables such as child labour, physical abuse and child neglect have negative relationship with academic performance of students.

\subsection{Recommendations}

Based on the findings of the study, the following recommendations are hereby put forward;

1. Government should embark on public enlightenment campaign on the social ills of child abuse.

2. Non-governmental organisation such as the National council for women Societies (NCWS) African Network for the prevention and protection Against Child Abuse and neglect (ANPPCAN), Planned Parenthood Federation of Nigeria (PPFN), world organisation for Early Childhood Education (WOECE), Rotary, Lion/Lioness Clubs, should be concerned over the plight of children who suffered one form of abuse or another.

3. Government should promulgate laws to guard against child abuse.

4. Government should make law that would protect the rights of the children.

5. Government should make education free at the primary and secondary level to enable children from poor family to go to school.

6. There should be increase in prosecution and convention of child abuses, and those who aid or abet it, as well as impose stricter sanctions against repeated offenders.

\section{References}

Adegun, O. A. (2013). Practices of child Labour Among Parents in Ekiti State, Nigeria: Implication for school Administrators. Journals of Education and Practices 4(11), 1-7.

Alokan, F. B. And Olatunji, I. C. (2014). Influence of Child Abuse on Classroom behavibours and Academic performance among primary and secondary school students Journals of European Scientific, 10(10), 131-140.

Awosusi, O., and Adebo, G. M. (2012). Domestic Servants and Rural Youth Urban Migration in Nigeria. International Journal of Humanities and Social Science 2(5) 271-278.

Bassey, E. N., Baghebo, M. and Otu, C. A. (2012). Child labour in Nigeria and its Economics Implications. A case study of Calabar Municipality. Research on Humanities and Social Sciences 2(9) 149-159.

Basu, V. (2008). Child Abuse, Gender, and Society. New York: Rutledge.

Bhart, B. A. (2009). Child labour in the handicraft home industry in Kashmir. Sociological study, Journals of International Non-government organisation 4(9) 391-400.

Coonan, T., Thompson, R. (2004). Ancient Evil, Modern face. The fight against human trafficking: George Town Journal Crime goes Global 6(1), 60-69.

Davey, J. (2010). The facts: modern Human Slavery and Trafficking. Retrieved June 15, 2010 from http://duskgeo.orst.edu/jdic>.

Denga, D. I. (2007). Child parenting in Developing Nations. Challenges and Prospects. Calabar: Rapid Educational Publishers.

Ekwe, A. O. (2002). In Odey, M. O. (2017). Health Hazards in child labour: A case for Juvenile hawkers. Paper Presented at the $1^{\text {st }}$ International Workshop on Child abuse and neglect in Africa. Enugu.

Eruba, J. O. (2004). In Ita, P. M. (2017). Family Influence on child attitude towards science, technology and mathematics education in Nigeria. The Journal of Family Development 1(1) 150-159.

Ezeadi, S. (2010). Government Secondary Schools and Tertiary Institutions. Onistha: Tabash Press.

Horsch, P. (2010). The Respective Classroom Approach: A caring, respectful school environment as a context for Development. Education and urban society, 34(3), 365-383.

Hosin, A. A. (2007). Responses to traumatized children Basingstock: Palgrave Macmillan. 
International Labour Organisation (ILO) (2013). Child labour: A textbook for University Students. Geneva.

Isandgedighi, A. J. (2005). Child abuse in R. O. Nnachi and Ezeh, P. S. (Eds) Child abuse and neglect Akwa: Erudition Publisher.

Moses, A. (2005). Social dimensions of Child Abuse. Akwa Erudition Publisher.

Obinaju, Q. I. (2005). Child abuse in Nigeria. The Journey so Far: Akwa: Erudition Publisher.

Okafor, G. (2010). Philosophy of Education and third world prospect in Nigeria. Owerri: Totan Publishers Ltd.

Sabates, W. R. and Rayah, F. (2011). Migration and social protection: Claiming Social Right beyond Borders. Rethinking International Development Series. Pal-grave Macmillan.

Springer, K. W., Sheridan, J. And Carnes, M. (2007). Longterm physical and mental health consequences of childhood physical abuse. Retrieved January, 3, 2007 from http://dx-doi.org/10. 106\% 2Fj.

Theoklitou, D. Kabitsis, N. (2012). Physical and Emotional abuse of primary school children by teacher. Child Abuse, 26(1) 64-70.

Umobong, M. E. (2010). Child abuse and its implications for the educational sector in Nigeria. A new Journal of African Studies 7(2) 106-118.

UNICEF (2010). United Nation Children Education Fund. Child abuse and neglect. Retrieved April 16, 2019 from http: www.unicef.com. 